\title{
Prion Protein Binds to Aldolase A Produced by Bovine Intestinal M Cells
}

\author{
Yuya Nagasawa', Yu Takahashi', Wataru Itani' ${ }^{1}$, Hitoshi Watanabe1, Yusuke Hidaka1, \\ Shotaro Morita1, Kei Suzuki', Kouichi Watanabe'1, Shyuichi Ohwada1, Haruki Kitazawa', \\ Morikazu Imamura ${ }^{3}$, Takashi Yokoyama ${ }^{3}$, Motohiro Horiuchi ${ }^{4}$, Suehiro Sakaguchi', \\ Shirou Mohri' ${ }^{3}$, Michael T. Rose ${ }^{6}$, Tomonori Nochi' ${ }^{1}$, Hisashi Aso ${ }^{*}$ \\ ${ }^{1}$ Cellular Biology Laboratory, Tohoku University, Sendai, Japan \\ ${ }^{2}$ Food Immunology Group, Tohoku University, Sendai, Japan \\ ${ }^{3}$ Prion Disease Research Center, National Institute of Animal Health, Tsukuba, Japan \\ ${ }^{4}$ Laboratory of Veterinary Hygiene, Hokkaido University, Sapporo, Japan \\ ${ }^{5}$ Institute for Enzyme Research, The University of Tokushima, Tokushima, Japan \\ ${ }^{6}$ Institute of Biological, Environmental and Rural Sciences, Aberystwyth University, Aberystwyth, UK \\ Email: asosan@bios.tohoku.ac.jp
}

Received 23 January 2015; accepted 1 March 2015; published 11 March 2015

Copyright (C) 2015 by authors and Scientific Research Publishing Inc.

This work is licensed under the Creative Commons Attribution International License (CC BY). http://creativecommons.org/licenses/by/4.0/

(c) (i) Open Access

\section{Abstract}

Microfold (M) cells are a kind of intestinal epithelial cell in the follicle-associated epithelium (FAE) of Peyer's patches. They can transport antigens and microorganisms to lymphoid tissues. Bovine spongiform encephalopathy (BSE) is a fatal neurodegenerative disorder in cattle. It is linked to variant Creutzfeldt-Jakob disease in humans. Although it is thought that M cells transport the BSE agent, the exact mechanism by which it crosses the intestinal barrier is not clear. We have bovine intestinal epithelial cell line (BIE cells), which can differentiate into the $M$ cell type in vitro after stimulation, and which is able to transport the BSE agent. We show here that $M$ cells are able to incorporate large numbers of PrP coated magnetic particles into intracellular vesicles, which we collected. The results of 2-DE show a specific protein associated with the PrP-coated particles, compared with non-coated particles. This protein was identified as aldolase A, a glycolytic pathway enzyme, using LC-MS/MS analysis. Aldolase A was synthesized and secreted by BIE cells, and increased during $M$ cell differentiation. In the villi of the bovine intestine, aldolase $A$ was detected on the surface of the epithelium and in the mucus droplet of goblet cells. In the FAE of bovine jejunal and ileal Peyer's patches, aldolase $A$ was localized on the surface and the apical part of the $M$ cells. The binding of rbPrP to aldolase A was clearly detected and inhibited by pre-treatment of anti-aldolase $A$ antibody. Aldolase $A$ was co-stained with incorporated $\mathrm{PrP}^{\mathrm{Sc}}$ in M-BIE cells. These results suggest that bovine $M$ cells and goblet cells synthesize aldolase $A$, and that aldolase $A$ may

\footnotetext{
"Corresponding author.
} 
have the ability to bind PrP and associate with PrP in cellular vesicles. Therefore, aldolase A-positive M cells may play a key role in the invasion of BSE into the body.

\title{
Keywords
}

\author{
Peyer's Patch, M Cell, BIE Cells, Aldolase A, PrP Binding Protein
}

\section{Introduction}

The mucosal surface of the gastrointestinal tract is continuously exposed to large numbers of commensal microorganisms and sporadically to pathogens. The gastrointestinal epithelium is covered by a protective mucus gel composed predominantly of mucin glycoproteins that are synthesized and secreted by goblet cells [1] [2]. Furthermore, there is a special immune system against pathogens and invasion of antigens in the gut-associated lymphoid tissue (GALT) [3] [4]. GALT is composed of lymphoid follicles along the length of the gastrointestinal tract. Most of the lymphoid follicles are isolated from each other; however, in the jejunum and ileum, they form lymphoid aggregates, known as Peyer's patches [5]-[8]. Peyer's patches are distributed along the small intestine, they play a very important role in GALT. Peyer's patches represent the primary site in the intestine for the uptake and presentation to the immune system of ingested pathogenic microorganisms and viruses, in several species such as sheep [9], cattle [10], pigs [11] and dogs [12]. In cattle, there are two types of Peyer's patches in the small intestine which differ in development, location, structure and function: one type in the jejunum has discrete patches and a second type in the ileum is long and continuous [10].

Microfold (M) cells are a kind of intestinal epithelial cell in the follicle-associated epithelium (FAE) of Peyer's patches. In general, $\mathrm{M}$ cells have a characteristic morphology different from the absorptive epithelium. Typically, $\mathrm{M}$ cells are characterized by a lack of almost all microvilli. In addition, the basement membrane of $\mathrm{M}$ cells forms a pocket structure that is deeply recessed, and they have a close connection with dendritic cells and lymphocytes [13] [14]. M cells can transport antigens and microorganisms using transport vesicles into underlying lymphoid tissues [15] [16], which contain all of the necessary lymphoid cells for the induction and regulation of antigen-specific IgA responses [17] [18]. In this way, antigen-presenting cells in the mucosal immune system encounter a variety of antigens that enter the body through $\mathrm{M}$ cells. The mechanisms of transcytosis in $\mathrm{M}$ cells remain unclear, however, despite the important role of $\mathrm{M}$ cells in mucosal defense.

Transmissible spongiform encephalopathies (TSE) or prion diseases, including human Creutzfeldt-Jakob disease (CJD) and endemic sheep scrapie, are fatal neurodegenerative disorders. Bovine spongiform encephalopathy (BSE) is a TSE of cattle. The first case of BSE in the world was found in the United Kingdom in 1986. By the end of 2000, more than 180,000 cases had been reported in the UK. BSE spread to continental Europe, North America, and Japan [19]. In the case of BSE in cattle, infection occurred through feeding concentrates with meat and bone meal derived from TSE infected sheep and cattle [20]. BSE became a major public health concern when evidence linked it to variant Creutzfeldt-Jakob disease (vCJD) in humans. Likewise, the transmission of vCJD to humans is likely to have occurred following the consumption of BSE-contaminated food [19] [21]. Replication of the infectious BSE agent depends critically on the host prion protein $\left(\operatorname{PrP}^{c}\right)$, which accumulates as an abnormal, detergent insoluble, relatively proteinase-resistant isoform, $\left(\mathrm{PrP}^{\text {res }}\right)$ in diseased tissues [22]. Although some studies have revealed that $\operatorname{PrP}^{\text {res }}$ does not correlate with infectivity levels in animal tissues as well as in subcellular fractions [23] [24], $\operatorname{PrP}^{\text {res }}$ is a useful surrogate marker for TSE infection.

Studies have shown that $\operatorname{PrP}^{\mathrm{Sc}}$ first have to cross M cells [25]-[27]. Our laboratory recently established that orally delivered $\operatorname{PrP}^{\mathrm{Sc}}$ were incorporated by $\mathrm{M}$ cells promptly, and then $\mathrm{CD} 11 \mathrm{~b}$ - and CD14-positive macrophages act as a transporter of incorporated $\operatorname{PrP}^{\mathrm{Sc}}$ from the Peyer's patches to other lymphoid tissues and the peripheral nervous system in the PrP knockout mice [25]. However, due to the difficulty of the research methods, the study of $\operatorname{PrP}^{\mathrm{Sc}}$ invasion mechanism through $\mathrm{M}$ cells is still unclear. We recently established a bovine intestinal epithelial cell line (BIE cells) that could differentiate into the $\mathrm{M}$ cell type in vitro after lymphocytic stimulation [28] and the possibility was shown that BIE cells were able to deliver TSE agents, such as the murineadapted BSE agent [29]. Thus, our laboratory has shown that in vitro M cell-differentiated BIE cells actively transcytose the BSE agent through to the basolateral side of the epithelial layer, and that prions are translocated 
across the FAE by M cells of PrP knockout mice. In this study, we investigated the PrP-binding proteins from vesicles of M cell-differentiated BIE cells by proteomic analysis. Then, we described the PrP binding of aldolase $\mathrm{A}$, which is synthesized and secreted in bovine $\mathrm{M}$ cells. Our findings accordingly elucidate the mechanism of uptake of $\operatorname{PrP}^{\mathrm{Sc}}$ in intestinal M cells.

\section{Materials and Methods}

\subsection{Animals and Tissue Preparation}

The duodenum, jejunum, ileum and colon were obtained from 6, 8 and 10-wk-old male Holstein calves (Miyagi Agriculture Public Corporation, Sendai, Japan). All animals were clinically healthy and free of infectious diseases. All experiments were permitted by the Tohoku University Environmental \& Safety Committee and conducted in accordance with the Guidelines for Animals Experimentation of Tohoku University, which have been sanctioned by the relevant committee of the Government of Japan based on the Declaration of Helsinki.

\subsection{Primary Antibodies}

Goat polyclonal anti-aldolase A antibody (LSB-1461, LSBio, Seattle, WA, diluted to 1:1000) was used for the immunohistochemistry, Western blot analysis, far-Western blot analysis and ELISA. Rabbit polyclonal anti-lysosome-associated membrane protein-1 (LAMP1), as a endosomal marker, antibody (ab24170, Abcam, Cambridge, UK; diluted to 1:200), rabbit polyclonal anti-mucin core protein 2 (MUC2), as a mucous marker, antibody (ab76774, Abcam, diluted to 1:1000) and mouse monoclonal cytokeratin (CK) 18 antibody, as a marker of bovine intestinal M cell (clone CY90, Sigma, St. Louis, MO, diluted to 1:1000) were used for the immunohistochemistry. The mouse monoclonal anti-His-probe antibody (clone H-3, Santa Cruz, Dallas, Texas, diluted in 1: 300) was used for far-Western blot analysis. The mouse monoclonal anti-PrP antibody (clone 132) [30] was used for the detection of $\mathrm{PrP}^{\mathrm{Sc}}$ by immunofluorescent staining. A goat IgG antibody (LSBio) was used as an isotype control antibody. Rabbit polyclonal anti-G-3-P dehydrogenase (GAPDH) antibody (ab9485, Abcam, diluted to 1:1000) was used as the internal standard for Western blot analysis.

\subsection{Production of Recombinant Bovine Prion Protein (rbPrP)}

A DNA fragment encoding amino acid residues 25 to 242 of bovine PrP was amplified by PCR from genomic DNA purified from bovine liver using the forward primer containing a NdeI site

(5'-TCTAGCTGTCATATGAAGAAGCGACCAAAACCTGG-3') and reverse primer containing a BamHI site (5'-AGCTGTGGATCCTCATCAACTTGCCCCTCGTTGGTAATAAG-3'). The PCR reaction was performed using a high fidelity heat resistant DNA polymerase (KOD, Toyobo, Osaka, Japan) and PCR conditions were 1 cycle of $2 \mathrm{~min}$ at $95^{\circ} \mathrm{C} 10 \mathrm{sec}$ at $58^{\circ} \mathrm{C}$, and $20 \mathrm{sec}$ at $68^{\circ} \mathrm{C}$, and finishing with $2 \mathrm{~min}$ incubation at $68^{\circ} \mathrm{C}$. The PCR fragment was cloned into pGEM-T Easy vector (Promega, Madison, WI) and the sequences of the inserts were confirmed by DNA sequencing. The inserts were excised with NdeI and BamHI from the plasmids, and were re-cloned into pET15b (Novagen, Madison, WI) encoding an N-terminal His-probe sequence, at NdeI andBamHI sites. The vectors carrying bovine PrP were transformed into E. coli BL21 (DE3) (Novagen).

The expression was carried out according to the manufacturer's instructions. The collected cells were solubilized in Bug buster (Novagen) containing $200 \mu \mathrm{g} / \mathrm{ml}$ lysozyme and $200 \mu \mathrm{g} / \mathrm{ml}$ DNase and then were centrifuged at $6000 \mathrm{~g}$ at $4^{\circ} \mathrm{C}$ for $30 \mathrm{~min}$. The pellet was separated into soluble and insoluble fractions by centrifugation at $6000 \mathrm{~g}$ at $4^{\circ} \mathrm{C}$ for $30 \mathrm{~min}$. The pellet was then solubilized by protein denaturation buffer (pH 8.0;6 M GuHCl/10 $\mathrm{mM}$ Tris-HCl/100 mM sodium phosphate/20 mM imidazole) and then subjected to SDS-PAGE for Coomassie brilliant Blue staining, and Western blot analysis using an anti-PrP monoclonal antibody (clone 6H4, Prionics, Schlieren-Zurich, Switzerland) and anti-His probe monoclonal antibody. Soluble proteins were applied to a Ni-NTA affinity column (Ni-NTA Superflow Cartridges, Qiagen, Hilden, Germany), which was equilibrated by denaturation buffer for $10 \mathrm{~min}$. After the column was washed with protein denaturation buffer for $10 \mathrm{~min}$, soluble proteins were refolded for $22 \mathrm{~h}$ by a linear gradient from denaturation buffer to binding buffer $(\mathrm{pH} 8.0 ; 10$ $\mathrm{mM}$ Tris-HCl/100 mM sodium phosphate/20 mM imidazole). Soluble proteins were eluted by elution buffer ( $\mathrm{pH}$ 5.8; $10 \mathrm{mM}$ Tris- $\mathrm{HCl} / 100 \mathrm{mM}$ sodium phosphate/500 mM Imidazole) and dialyzed to $10 \mathrm{mM}$ sodium phosphate using a dialysis membrane (Eidia, Tokyo, JP). The purity of rbPrP was separated by SDS-PAGE, stained by Coomassie brilliant blue and determined using CS Analyzer software. 


\subsection{Induction of M Cell Differentiation in BIE Cells}

The bovine intestinal epithelial cell line (BIE cells) [28] [29] was maintained in Dulbecco's modified Eagle medium (DMEM, GIBCO, Grand Island, NY) containing 10\% heat-inactivated fetal bovine serum (FBS, Hananesco Bio, Tokyo, JP), penicillin (GIBCO, $10 \mathrm{U} / \mathrm{ml})$ and streptomycin $(10 \mathrm{mg} / \mathrm{ml})$ until it was differentiated into the $\mathrm{M}$ cell type and used for the studies described below.

To induce M cell differentiation, BIE cells were seeded onto each well of 12 -Transwell inserts $\left(9 \times 10^{5}\right.$ cells/ well, 3.0- $\mu \mathrm{m}$-pore-size Transwell filter polycarbonate membrane; Corning, NY, US) and cultured for 3 days. The cells were treated with or without the IL-2-stimulated PBMC culture supernatant for another 3 days [31]. Transepithelial electrical resistance (TER) was measured by Millicell-ERS (Millipore, Billerica, MA) every day. The unit of measurement was ohms per centimeter squared, and the values were determined by subtracting the blank well TER from the test well TER and dividing this by the surface area of the well. In order to evaluate the effect of aldolase A on the transcytosis activity of BIE and M-BIE cells, BIE and M-BIE cells were pretreated with or without goat anti-aldolase A (diluted to 1:200) or control goat IgG antibody (LSBio, diluted to 1:200) for 2 hours, and $1.35 \times 10^{8}$ non-coated (Non) or PrP-coated particles were added to the apical surface of them. After $9 \mathrm{~h}$ of incubation, the basal medium of the BIE and M-BIE cells were collected, and the transported particles were quantified using a FACS Calibur flow cytometer (Becton Dickinson, San Jose, CA).

\subsection{Scanning Electron Microscopy (SEM)}

BIE cells were seeded on Transwell-inserts at $9.0 \times 10^{5}$ cells $/ 1.12 \mathrm{~cm}^{2} /$ well and cultured for 3 days. The cells were treated with or without the IL-2-stimulated PBMC culture supernatant for another 3 days. These cells were washed once with $0.1 \mathrm{M}$ phosphate buffer ( $\mathrm{pH} 7.4$ ) and then fixed with $2.5 \%$ glutaraldehyde in $0.1 \mathrm{M}$ phosphate buffer (PB) for $1 \mathrm{~h}$. Following three times washing with $0.1 \mathrm{M} \mathrm{PB}$, the cells were dehydrated by passage through graded dilutions of ethanol and substituted with t-butylalcohol. The cells were freeze-dried, coated with platinum-palladium and observed by SEM (SU8000, Hitachi, Tokyo, Japan).

\subsection{Establishment of BNP (Bovine Neuronal Progenitor) Cells}

The caudate nucleus was removed from a cow ( 8 months old) after slaughter, and transferred to serum-free DMEM supplemented with penicillin (GIBCO, $10 \mathrm{U} / \mathrm{ml})$ and streptomycin $(10 \mathrm{mg} / \mathrm{ml})$. The caudate nucleus was cut finely, washed three times with serum-free DMEM, and centrifuged at $200 \mathrm{~g}$ for $7 \mathrm{~min}$. The cells were re-suspended in 10\% FBS-DMEM and seeded into a flask (Nunc, Rothskilde, Denmark). All cultures were maintained at $37^{\circ} \mathrm{C}$ and $5 \% \mathrm{CO}_{2}$ in a humidified incubator. The cells were treated with a EDTA buffer (pH 7.5; 0.36\% EDTA, $0.1 \%$ BSA in PBS) for a few minutes, detached by $0.04 \%$ trypsin/PBS, and then collected and passaged when they reached $70 \%$ confluence. The cells in primary culture were transformed by the SV40 large $\mathrm{T}$ antigen gene and cloned by limiting dilution, according to the method used for the BIE cell line [28]. Each well of a 96-well plate was microscopically checked for cell growth and monoclonal expansion at 5 days after plating. Using this methodology, 18 clones were established. Wells for which it was certain there was a single colony of rapidly growing cells with neural-like morphology were marked. All cell lines were expressed in Hes1 which is the signal-related factors and related to maintenance of neural stem cells, Nestin which is a marker for neural stem cells, Ptch1 which is the receptor for sonic hedgehog, Fzd4 which is related to Wnt signaling pathway, and Oct 4 which is a maker for undifferentiated cells (data not shown). The clone number 3 cell line was used in experiments because it expressed aldolase A strongly (data not shown).

\subsection{Preparation of PrPsc from N2aC24 L1-3 Cells}

Murine neuroblastoma N2aC24 cells overexpressing mouse $\operatorname{PrP}^{\mathrm{c}}$ were exposed to the murine-adapted $22 \mathrm{~L}$ scrapie prion, and the $22 \mathrm{~L}$ prion-infected N2aC24 clone, designed N2aC24L1-3, were obtained by limiting dilution [32] [33]. N2aC24 L1-3 cells were maintained in DMEM containing 10\% FBS, penicillin (GIBCO, 10 $\mathrm{U} / \mathrm{ml}$ ) and streptomycin $(10 \mathrm{mg} / \mathrm{ml})$. N2aC24L1-3 cells were seeded to $6 \times 10^{3}$ cells/ $/ \mathrm{cm}^{2} 225 \mathrm{~cm}^{2}$ flask (BD Falcon ${ }^{\mathrm{TM}}$ Cell Culture Flasks, Falcon, Oxnard, CA). After 3 days of culture, the cells were homogenized each ten times in $1 \mathrm{ml}$ of PBS by $21 \mathrm{G}, 25 \mathrm{G}$ and $27 \mathrm{G}$ syringe (Terumo, Tokyo, JP).

\subsection{Proteomic Analysis of PrP Specific Binding Proteins in M-BIE Cells}

After M cell differentiation, non-coated or PrP-coated magnetic particles were added to the surface of M-BIE 
cells. After $9 \mathrm{~h}$ of incubation, these cells were homogenized in Tris-Triton X buffer (10 mM Tris-HCl, $150 \mathrm{mM}$ $\mathrm{NaCl}, 0.5 \%$ Triton X-100, $0.2 \mathrm{mM}$ phenylmethylsulfonyl fluoride). The vesicles containing magnetic particles were collected from the lysate of M-BIE cells using the magnetic stand and the membrane proteins were extracted using a Transmembrane protein Extraction Kit (Novagen). The electrophoresis protein samples were diluted 1:9 in sample buffer (40 mM Tris- $\mathrm{HCl} \mathrm{pH}$ 6.8, $0.25 \mathrm{mM}$ DTT, $7.5 \mathrm{M}$ urea, 2.3\% (w/v) SDS), centrifuged at 22,000 $\mathrm{g}$ at $4^{\circ} \mathrm{C}$ for $30 \mathrm{~min}$, and then the supernatants were collected. The supernatant was diluted 9:1 in $1 \mathrm{M}$ acrylamide (Sigma). The protein samples were separated on agar gels (pH $3-10,7.5 \mathrm{~cm}$ long, ATTO) using isoelectric point electrophoresis apparatus, (Disc-Run ATTO) at $300 \mathrm{~V}$ for $210 \mathrm{~min}$. Each well was loaded with $1.5 \mathrm{mg}$ of total proteins. The agar gels were fixed with $2.5 \%$ trichloroacetic acid for $3 \mathrm{~min}$ and then washed three times in Milli Q water. Second-dimension electrophoresis was performed on $12.5 \%$ polyacrylamide gradient gels in PAGE Run (ATTO). The agar gels were run at $20 \mathrm{~mA}$ for $90 \mathrm{~min}$. Proteins were visualized using a Silver Stain Kit (Wako, Osaka, JP). The specific spots in PrP-coated magnetic particles were identified, compared with those in non-coated particles. The protein spots indicated were excised and digested with trypsin overnight at $35^{\circ} \mathrm{C}$ and the resulting peptides separated by LC-MS/MS analysis (Japan Proteomics Co, Ltd.; Sendai, JP) (Table 1). Data generated were subjected to NCBInr databases searching using as programs MASCOT. In MASCOT program, probability-based MOWSE scores greater than 61 were considered significant $(p<0.05)$ [34].

\subsection{Western Blot Analysis}

BIE cells and M-BIE cells were homogenized in Tris-Triton X buffer. The total protein concentration was measured by the Bicinchoninic Acid Protein Assay Kit (Thermo Fisher Scientific, Waltham, MA). The lysates were re-suspended in SDS loading buffer (50 mM Tris- $\mathrm{HCl}$ [pH 6.8] containing 5\% glycerol, $1.6 \%$ SDS, and $100 \mathrm{mM}$ dithiothreitol) and loaded onto a 12\% polyacrylamide gel after boiling for $5 \mathrm{~min}$. The proteins were transferred onto an Immobilon-P membrane (Millipore, Billerica, MA) in transfer buffer containing $20 \%$ methanol at 1.2 $\mathrm{mA} / \mathrm{cm}^{2}$ for $60 \mathrm{~min}$, and then the membrane was blocked in 3\% skim milk in TBST (100 mM Tris-HCl [pH 7.8], $100 \mathrm{mM} \mathrm{NaCl}$, and $0.1 \%$ Tween-20) for $1 \mathrm{~h}$ at room temperature (RT). After blocking, the membrane was incubated with goat polyclonal anti-aldolase A antibody or rabbit polyclonal anti-GAPDH antibody for $14 \mathrm{~h}$ at $4^{\circ} \mathrm{C}$. Following three TBST washing cycles, the blot was incubated with alkaline phosphatase (AP)-conjugated rabbit anti-goat IgG (81-1622, Zymed Labs, CA, USA, diluted in 1:10,000) or AP-conjugated rabbit anti-rabbit IgG (A3687, Sigma, diluted in 1:10,000) as the secondary antibody for $1 \mathrm{~h}$ at RT. After three TBST washing cycles, the immunoreactive bands were visualized by an enhanced chemiluminescence system (ECL plus; Amersham Pharmacia Biotech, Piscataway, NJ).The apical and basal media from the Transwell culture of BIE and M-BIE cells were diluted 1:5 in SDS loading buffer. After boiling for 5 min, $15 \mu$ of samples were loaded onto a 12\% polyacrylamide gel and transferred onto an Immobilon-P membrane (Millipore) in transfer buffer containing $20 \%$ methanol at $1.2 \mathrm{~mA} / \mathrm{cm}^{2}$ for $60 \mathrm{~min}$. The membrane was blocked in3\% skim milk in TBST for $1 \mathrm{~h}$ at RT.

Table 1. PrP-binding protein identified by LC-MS/MS analysis.

\begin{tabular}{|c|c|c|c|c|c|}
\hline \multirow[b]{2}{*}{ Protein name ${ }^{a}$} & \multirow[b]{2}{*}{ Accno $^{\mathrm{b}}$} & \multicolumn{2}{|c|}{$\mathrm{kDa} / \mathrm{PI}$} & \multirow{2}{*}{$\begin{array}{l}\text { Peptide } \\
\text { matches } \\
(\mathrm{n})^{\mathrm{e}}\end{array}$} & \multirow{2}{*}{ Score $^{\mathrm{f}}$} \\
\hline & & Theoretical $^{\mathrm{c}}$ & Observed $^{d}$ & & \\
\hline Fructose-bisphoaphate aldolase A [Bostauras] & NP_001095385 & $39 / 8.4$ & $40 / 8.4$ & 4 & 213 \\
\hline Aldolase [Mustelaputoriusfuro] & ABN58928 & $34 / 7.9$ & $40 / 8.4$ & 2 & 99 \\
\hline Fructose-bisphoaphate aldolase C [Salmosalar] & NP_001135182 & $40 / 6.6$ & $40 / 8.4$ & 1 & 62 \\
\hline Fructose-bisphoaphate aldolase C [Callorhinchuscallorynchus] & BAD17946 & $37 / 5.1$ & $40 / 8.4$ & 1 & 57 \\
\hline Anionic tripsin precursor [Rattusnorvegicus] & NP_036767 & $26 / 4.7$ & $40 / 8.4$ & 2 & 52 \\
\hline Cobalt-containing nitrile hydratase subunit alpha & P21219 & $23 / 4.8$ & $40 / 8.4$ & 1 & 47 \\
\hline Protease, serine, 1 [Musmusculus] & AАH94921 & $26 / 4.8$ & $40 / 8.4$ & 1 & 44 \\
\hline Hypothetical transcriptional regulator, TetR family protein & ZP_01221408.1 & $23 / 5.2$ & $40 / 8.4$ & 2 & 38 \\
\hline Orf3 [Pseudomonas putida] & BAB62048 & $27 / 9.9$ & $40 / 8.4$ & 1 & 31 \\
\hline
\end{tabular}

All these proteins were obtained from the single circled spot in Figures $3(\mathrm{~A}) .{ }^{\mathrm{a}, \mathrm{b}}$ Protein names and accession numbers are given according to National Center of Biotechnology Information, NCBI; ${ }^{\mathrm{C}}$ Theoretical isoelectric point (PI) and molecular mass ( $\mathrm{kDa}$ ); ${ }^{\mathrm{d}}$ Observed isoelectric point (PI) and mo-

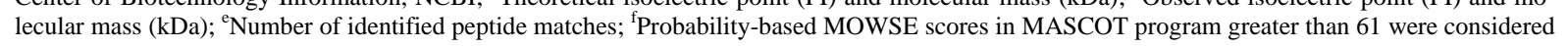
significant $(p<0.05)$. 
After blocking, the membrane was incubated with goat anti-aldolase A polyclonal antibody for $14 \mathrm{~h}$ at $4^{\circ} \mathrm{C}$. Following three TBST washing cycles, the blot was incubated with HRP-conjugated bovine anti-goat IgG as the secondary antibody (805-005-180, Jackson Immuno Research Europe Ltd., Suffolk, UK) for $1 \mathrm{~h}$ at RT. After three TBST washing cycles, immunoreactive bands were visualized by an enhanced chemiluminescence system (EZ-Capture MG, ATTO).

\subsection{Far-Western Blot Analysis}

The lysate of BNP cells was separated by SDS-PAGE and transferred onto an Immobilon-P membrane in transfer buffer containing $20 \%$ methanol for $60 \mathrm{~min}$. The lysate was separated by SDS-PAGE and subjected to the Western blot analysis described above. The membrane was blocked in 3\% skim milk in TBST for $1 \mathrm{~h}$ at RT and the membrane was incubated with or without goat polyclonal anti-aldolase A antibody for $14 \mathrm{~h}$ at $4^{\circ} \mathrm{C}$. After the washing three times in TBST, the membrane was incubated with or without $100 \mu \mathrm{g} / \mathrm{mL} \mathrm{rbPrP}$ in blocking buffer for $14 \mathrm{~h}$ at $4^{\circ} \mathrm{C}$. The membrane was washed three times for 5 min with TBST. The rbPrP-bounding on the membrane was incubated with the mouse monoclonal anti-His-probe antibody in blocking buffer for $1 \mathrm{~h}$ at RT. Following three TBST washing cycles, the membrane was incubated with AP-conjugated goat anti-mouse IgG as the secondary antibody (A3562, Sigma, diluted in 1:50,000) for $1 \mathrm{~h}$ at RT. After three TBST washing cycles, the immunoreactive bands were visualized by an enhanced chemiluminescence system.

\subsection{Immunoprecipitation}

Protein (40 $\mu$ l) G-Sepharose 50\% solution (GE Healthcare Life Sciences, Uppsala, Sweden) was added to a 40 $\mu \mathrm{l}$ mixture of rbPrP $(1 \mu \mathrm{g})$ and aldolase from rabbit muscles $(1 \mu \mathrm{g}$; Sigma), and incubated under rotational agitation at $4^{\circ} \mathrm{C}$ for $30 \mathrm{~min}$ in Tris-Triton $\mathrm{X}$ buffer. The mixture was centrifuged at $9200 \mathrm{~g}$ at $4^{\circ} \mathrm{C}$ for $1 \mathrm{~min}$. The supernatant was collected. Anti-aldolase A antibody $(5 \mu \mathrm{g})$ was added to it and incubated under rotational agitation at $4^{\circ} \mathrm{C}$ for $30 \mathrm{~min}$ by Tris-Triton X buffer. Protein G-Sepharose $50 \%$ solution (40 $\left.\mu \mathrm{l}\right)$ was added to it, then suspended and incubated under rotation at $4^{\circ} \mathrm{C}$ for $30 \mathrm{~min}$. Beads were centrifuged at $9200 \mathrm{~g}$ at $4^{\circ} \mathrm{C}$ for $1 \mathrm{~min}$. The pellet was washed with PBS, incubated in $20 \mu \mathrm{l}$ of SDS loading buffer at $95^{\circ} \mathrm{C}$ for $5 \mathrm{~min}$, and then subjected to the SDS-PAGE analysis.

\subsection{Enzyme-Linked Immuno Sorbent Assay (ELISA) for Aldolase A-Binding to rbPrP}

rbPrP in carbonate-bicarbonate buffer (Sigma) was incubated at $2 \mu \mathrm{g} / \mathrm{ml}$ in 96 well ELISA plates (C96 Maxisorp cert. Nunc-Immuno Plate, Thermo Fisher Scientific, Waltham, MA) for $14 \mathrm{~h}$ at $4^{\circ} \mathrm{C}$. After three TBST washing cycles, the wells were incubated with apical and basal media from the Transwell culture of BIE and M-BIE cells for $1 \mathrm{~h}$ at RT. After three TBST washing cycles, and the wells were then blocked with $1 \%$ BSA for $1 \mathrm{~h}$ to prevent nonspecific reactions and then the wells were treated with goat anti-aldolase A antibody for $2 \mathrm{~h}$ at RT. Following three TBST washing cycles, the wells were incubated with HRP-conjugated bovine anti-goat IgG as the secondary antibody (805-005-180, Jackson ImmunoResearch Europe Ltd.) for $1 \mathrm{~h}$ at RT. The freshly prepared substrate was added and the OD was taken at $450 \mathrm{~nm}$ using the TMB microwell peroxidase substrate system (KPL, Gaithersburg, Maryland). Negative control assays were performed without the apical and basal media.

\subsection{Immunohistochemistry}

Tissue samples from 6, 8 or 10 -wk-old calves were fixed with $4 \%$ paraformaldehyde solution in $0.1 \mathrm{M}$ phosphate buffer (PB) for $24 \mathrm{~h}$ at $4^{\circ} \mathrm{C}$. Tissues were dehydrated through a series of graded ethanol solutions and embedded in paraffin. Three serial sections were cut at $4 \mu \mathrm{m}$ and mounted on glass slides (MAS-coated Superfrost; Matsunami, Osaka, JP). The sections were incubated with 0.05\% proteinase (Type XXIV: Bacterial, P8038; Sigma) in Tris-HCl buffer (pH 7.5) for 5 min at $37^{\circ} \mathrm{C}$, and treated with $3 \%$ normal chicken serum for 30 min to prevent nonspecific reactions of antibodies. Subsequently, the sections were incubated with goat anti-aldolase A polyclonal antibody at $4^{\circ} \mathrm{C}$ overnight. After the section was washed three times with PBS, Alexa Fluor 488 or 594-conjugated chicken anti-goat IgG (Molecular Probes, Leiden, The Netherlands, 1:400) was used as the secondary antibody for $1 \mathrm{~h}$ at RT, and then counterstained with 4, 6-diamidino-2-phenylindole (DAPI) and then examined using a confocal laser microscope (LSM7000, Carl Zeiss, Oberkochen, Germany). In order to determine the specificity of the immunostaining, negative controls were run in which the primary antibody was omitted (data not shown). After M cell differentiation, FITC-conjugated particles or $\mathrm{PrP}^{\mathrm{Sc}}$ of $\mathrm{N} 2 \mathrm{aC} 24$ cells were 
added to the surface of the BIE or M-BIE cells on Transwell inserts. After $9 \mathrm{~h}$ incubation, the cells were washed with PBS, fixed in 4\% PFA for 30 min at RT, and treated with 3\% normal chicken serum for 30 min to prevent nonspecific reactions. Subsequently, the samples were incubated with anti-aldolase A antibody at $4{ }^{\circ} \mathrm{C}$ overnight. After three PBS washing cycles, the samples were treated with Alexa Fluor 594-conjugated chicken anti-goat IgG as the secondary antibody for $1 \mathrm{~h}$, counterstained with DAPI for $5 \mathrm{~min}$, and then examined by a confocal laser microscope. For the detection of $\operatorname{PrP}^{\mathrm{Sc}}$, the sections were treated with $5 \mathrm{M}$ guanidine hydrochloride (Wako, Osaka, JP) for $10 \mathrm{~min}$ at RT and treated with 3\% normal chicken serum for $30 \mathrm{~min}$ to prevent nonspecific reactions. Subsequently, the samples were incubated with anti-PrP antibody clone 132 (diluted $1: 1000$ ) at $4^{\circ} \mathrm{C}$ overnight. After three PBS washing cycles, the samples were treated with Alexa Fluor 488-conjugated chicken antigoat IgG as the secondary antibody for $1 \mathrm{~h}$, and then counterstained with DAPI for $5 \mathrm{~min}$, and examined by a confocal laser microscope.

\subsection{Immunoelectron Microscopy}

Bovine ileal tissues were fixed in $4 \%$ paraformaldehyde in $0.1 \mathrm{M} \mathrm{PB}(\mathrm{pH} 7.4)$ for $14 \mathrm{~h}$ at $4{ }^{\circ} \mathrm{C}$. The fixed samples were washed three times with PB, dehydrated in a graded ethanol series, infiltrated with LR White (Plano, München, Germany), and sectioned into 60 - $80 \mathrm{~nm}$ thicknesses by ultramicrotome. The sections were mounted on formvar-coated nickel grids, and subsequently blocked with $1 \%$ bovine serum albumin, $3 \%$ skim milk and goat serum for $30 \mathrm{~min}$ at RT. The grids were then incubated for $14 \mathrm{~h}$ with goat anti-aldolase A antibody at a 1:1000 dilution. After washing with PB, the preparations were incubated for $1 \mathrm{~h}$ with rabbit anti-goat IgG conjugated to $15 \mathrm{~nm}$ gold particles (BBI solution, Cardiff, UK) diluted in 1:200. Sections were washed five times with $\mathrm{PB}$ and were fixed with $2.5 \%$ glutaraldehyde in $0.1 \mathrm{M} \mathrm{PB}(\mathrm{pH} 7.4$ ) for $10 \mathrm{~min}$ and then were washed in distilled water. The sections were examined by TEM (H8100, Hitachi).

\subsection{Statistical Analysis}

The data for the semi-quantitative analysis of protein expression and volume of transported particles are presented as mean $\pm \mathrm{SD}$. Student's t-tests were performed to determine if the relative change was statistically significant. A significant difference was determined at $p<0.05$.

\section{Results}

Recombinant bovine PrP (rbPrP) (aa 23 - 242) was expressed in E.coli from the modified pET-15b expression vector. Following purification and refolding in vitro, the recombinant protein was analyzed by Coomassie staining (Figure 1(A)) and Western blotting with 6H4 anti-PrP antibody (Figure 1(B)) or anti-His-probe antibody (Figure $1(\mathrm{C})$ ). The protein had a molecular mass of approximately $26 \mathrm{kDa}$. After the refolding using a Ni-NTA

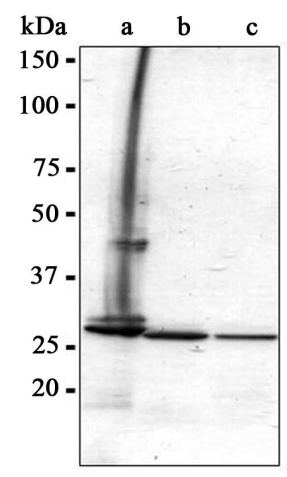

(A)

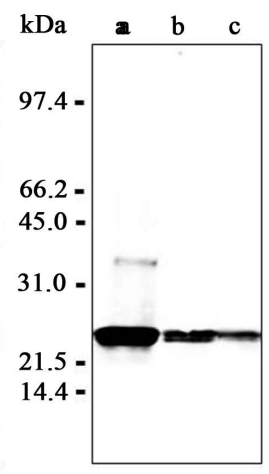

(B)

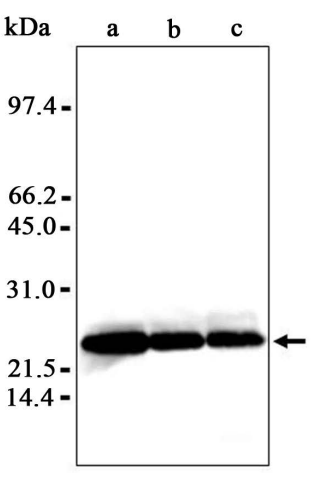

(C)

Figure 1. SDS-PAGE and Western blot analysis of rbPrP.The photographs of rbPrP show the SDSPAGE stained with Coomassie brilliant blue (A), and Western blot analysis with anti-PrP monoclonal antibody (B) or anti-His probe monoclonal antibody (C) at successive purification stages. The bovine prion protein was expressed in E. coli BL21 and then solubilized by protein denaturation buffer (a). The protein was applied to a Ni-NTA affinity column and eluted by elution buffer (b). The eluted protein was dialyzed to $10 \mathrm{mM}$ sodium phosphate (c). 
affinity column, the soluble protein was detected as a single band at $26 \mathrm{kDa}$ with Coomassie staining. The purity of rbPrP stained by Coomassie staining and Western blotting was estimated to be approximately $57 \%$ before the refolding, $92 \%$ after the refolding, and $97 \%$ after the dialysis using a CS Analyzer.

Initially, we confirmed the TER of BIE cell and M cell differentiated cells (M-BIE cells) cultured on Transwell-inserts. TER is widely used to describe the permeable properties of tight junctions between epithelial cells [35]. After 4 days of culture, these cells had already reached plateau of a maximally high TER value (Figure 2(A)). We successfully induced BIE cells to differentiate into the $\mathrm{M}$ cell type, monitored by determining the active transportation of PrP-coated particles or non-coated particles into the basal compartment. After $9 \mathrm{~h}$ of incubation of the particles, we detected a large number of particles in the basal medium of M-BIE cells (Figure 2(B)). Moreover, M-BIE cells transported PrP-coated particles to a greater extent than non-coated particles. In contrast, we detected few particles in the basal medium of BIE cells. SEM analysis revealed that the monocultured BIE cells for 6 days developed some short and irregular microvilli (Figure 2(C)). Following treatment with $\mathrm{M}$ cell differentiated medium, the microvilli disappeared from the surface of the BIE cells, took on a smooth appearance coincident with an enhanced ability to incorporate non- and PrP-coated particles. These data indicate that BIE cells are able to differentiate into $\mathrm{M}$ cells following stimulation, and that they preferentially transport PrP-coated particles.

We next performed a proteomic analysis of PrP-binding proteins in vesicles of M-BIE cells. After M cell differentiation of BIE cells, non-coated or PrP-coated magnetic particles were added to the surface of M-BIE cells. After $9 \mathrm{~h}$ of incubation, the vesicles containing magnetic particles were collected from M-BIE cells using the magnetic stand. The results of the 2-DE show that there is a specific spot identified in PrP-coated particles, indicated by a circle, compared with non-coated particles (Figure 3(A)). The protein spot was excised and subjected to LC-MS/MS analysis. The identification of the spots that are different between the two runs are presented in Table 1. We thus identified a glycolytic pathway enzyme, aldolase A, as a specific PrP-binding protein in M-BIE cells. Western blot analysis revealed that BIE cells synthesized aldolase A, and that the total amount of BIE cells increased during M cell differentiation (Figure 3(B) and Figure 3(C)).

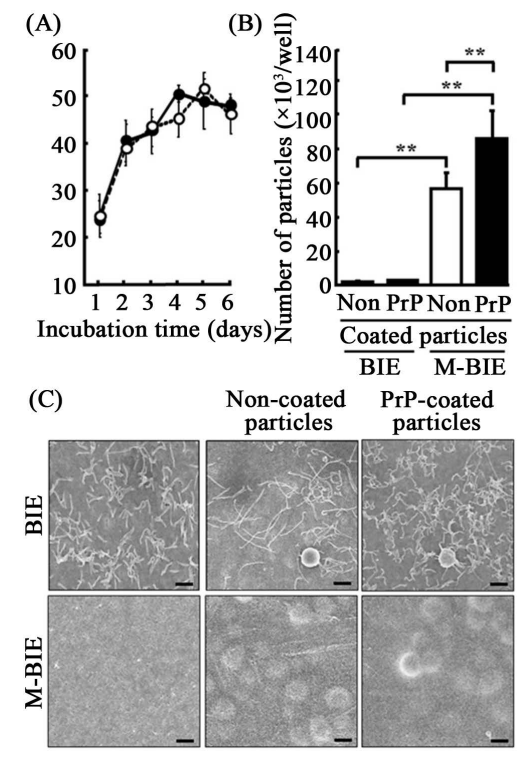

Figure 2. Transcytosis of prion protein coated particles of M cell-differentiated BIE cells. BIE cells were cultured in six Transwell inserts each for 3 days and stimulated with or without differentiation medium for another 3 days. In order to describe the permeable properties of tight junctions in undifferentiated (open circles) or M cell-differentiated BIE cells (closed circles), transepithelial electrical resistance (TER) was measured every day by using the Millicell-ERS (A). Non-coated or prion protein-coated particles were added to the apical medium. The basal media were collected after $9 \mathrm{~h}$. M cell differentiated BIE cells (M-BIE) transported PrP-particles to a greater extent than "Non" particles. The transported particles were quantified using a FACScalibur flow cytometer (B). After washing with PBS, BIE cells were fixed with glutaraldehyde and coated with platinum-palladium for SEM (C). Columns with anasterisk $\left(^{* *}\right)$ indicate a statistically significant difference $(p<0.01)$. Magnification $\times 12,000$. Bars $=1 \mu \mathrm{m}$. 

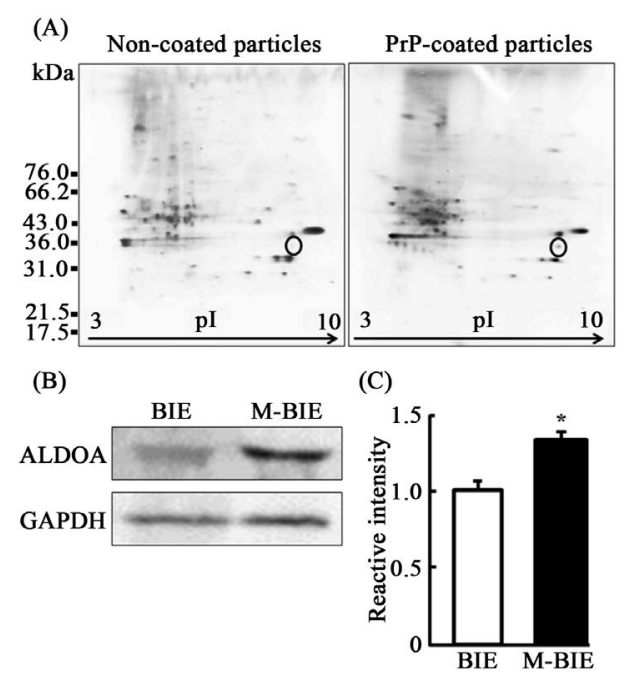

\begin{abstract}
Figure 3. Identification of aldolase A as a PrP binding proteins in the vesicles of M-BIE cells. After M celldifferentiation of BIE cells, non-coated or PrP-coated magnetic particles were added to the apical medium. After $9 \mathrm{~h}$, the vesicles containing magnetic particles were collected from M-BIE cells using a magnetic stand and then subjected to two-dimensional electrophoresis (A). Proteins in the gels were stained with a silver stain. The spot identified with a circle was the PrP-coated particles present at a much greater extent compared with the non-coated particles. The specific spot was excised and subjected to LC-MS/MS analysis, and this was identified aldolase A. The resulting identifications are summarized in Table 1 . The expression levels of aldolase A in BIE and M-BIE cells were analyzed at a band of approximately $39 \mathrm{kDa}$ by Western blot analysis (B). The band intensities of aldolase A $(n=6)$ were normalized with GAPDH and are presented as means \pm SD by densitometric analysis $(\mathrm{C})$. The asterisk $\left(^{*}\right)$ indicates a statistically significant difference $(p<0.05)$.
\end{abstract}

In order to confirm the binding between aldolase $\mathrm{A}$ and PrP, we performed a far-Western blot analysis. Aldolase A of BNP cells were detected in $39 \mathrm{kDa}$ using goat anti-aldolase A antibody (ALD-Ab) (Figure 4(A)-a). When the membranes were pre-treated with rbPrP, the binding of $\operatorname{rbPrP}$ to aldolase A was clearly stained with anti-His-probe antibody at $39 \mathrm{kDa}$, the same position of aldolase A (Figure 4(A)-b and Figure 4(A)-e), but not in the membrane without pre-treatment of rbPrP (Figure 4(A)-d). The binding of rbPrP to aldolase A was clearly inhibited by the pre-treatment of an anti-aldolase A antibody in the far-Western blot analysis (Figure 4(A)-c). We next investigated whether rbPrP could interact with aldolase A using immunoprecipitation by goat anti-aldolase A antibody or control goat IgG. When goat anti-aldolase A was used as a 1st antibody, the immunoreactive line was detected at $39 \mathrm{kDa}$ by anti-aldolase A antibody and at $26 \mathrm{kDa}$ by anti-PrP $6 \mathrm{H} 4$ antibody, but not at using control goat IgG as a 1st antibody (Figure 4(B)-a-d). These results suggest that aldolase A may have the ability to bind to PrP.

We examined whether $\mathrm{M}$ cells were able to secrete aldolase A or not. After $\mathrm{M}$ cell differentiation, BIE and MBIE cells on Transwell inserts were incubated for 9 hours, and the apical and basal media were collected. Western blot analysis shows that the production of aldolase A by BIE and M-BIE cells is greater to the apical medium than to the basal medium. As the concentration of aldolase A from M-BIE cells was fourfold greater than that from BIE cells, the secretory ability of aldolase A in BIE cells increased following $\mathrm{M}$ cell differentiation (Figure 5(A)). In addition, we investigated whether the aldolase A secreted from BIE cells bound to PrP or not. ELISA analysis demonstrated that aldolase A secreted from BIE cells and M-BIE cells was able to bind to PrP (Figure 5(B)). Negative controls without the apical and basal medium were devoid of the protein (data not shown).

We next investigated whether aldolase A was concerned with the transcytosis of PrP in M cells. After the addition of non- or PrP-coated particles, M-BIE cells incorporated a large number of each particle into their cytosol during a $9 \mathrm{~h}$ incubation (Figure 6(D) and Figure 6(E)), but BIE cells incorporated few (Figure 6(A) and Figure 6(B)). Aldolase A was located in the apical part of the BIE and M-BIE cells, and expressed to a greater extent in M-BIE cells than in BIE cells (Figure 6(A), Figure 6(B), Figure 6(D) and Figure 6(E)). The X-Z section shows the incorporated particles around and under the nuclei of M-BIE cells, and the co-existence of aldolase A and particles in the transporting vesicles in M-BIE cells (Figure 6(C) and Figure 6(D)). In addition, the 


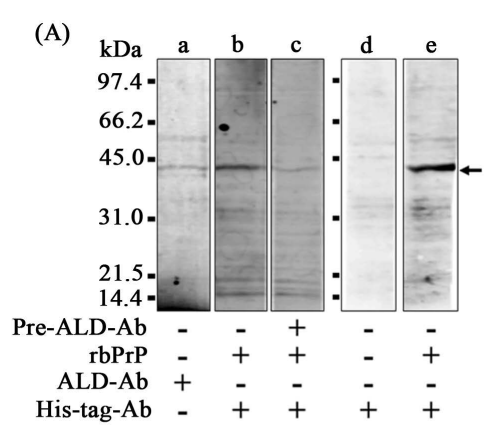

(B)

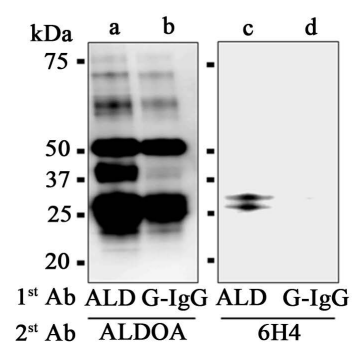

Figure 4. The binding of PrP to aldolase A by far-western blot analysis and immunoprecipitation. The cell lysate of BNP cells was separated by SDS-PAGE (A). The blot of this gel separation was subjected to Western blot analysis for anti-aldolase A antibody (a). The membranes were treated with rbPrP and then stained with anti-His-tag antibody as a probe in far-Western blot analysis ((b); (c); (e)). The binding of PrP to aldolase A was inhibited by pretreatment with the anti-aldolase A antibody (c). The lane $\mathrm{d}$ is a control as anti-His-tag antibody. The arrow in A indicates the aldolase A band.The mixture of rbPrP and aldolase Awas immunoprecipitated with goat anti-aldolase A antibody (ALD) or goat IgG control antibody (G-IgG) (B). Each immunoprecipitate was separated by SDS-PAGE and subjected to Western blot analysis with anti-aldolase A antibody (ALDOA) ((a) and (b)) or anti-PrP antibody (6H4) ((c) and (d)).
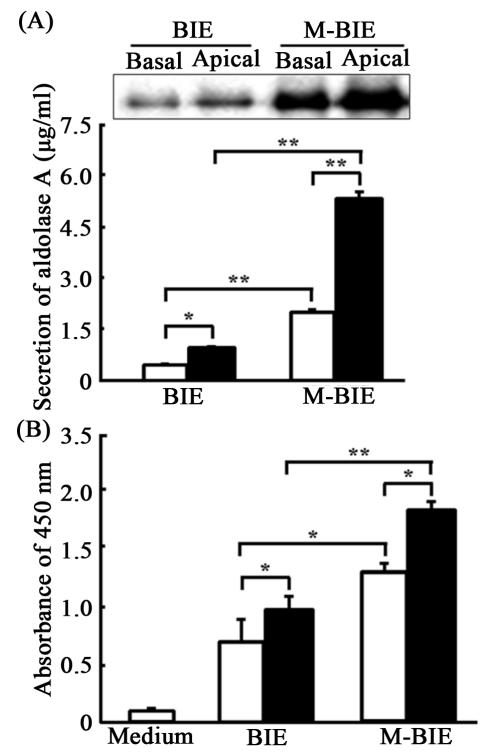

Figure 5. Secretion of aldolase A from BIE cells. After M cell differentiation, BIE and M cell-differentiated BIE (M-BIE) cells were incubated on Transwell inserts with fresh culture medium for $9 \mathrm{~h}$ (six wells each). The apical and basal media were collected and subjected to Western blot analysis using anti-aldolase A antibody. NIH Image software was used and normalized to the value of the basal medium of BIE cells (A). After 3 days of culture, the apical and basal media were collected from BIE and M-BIE cells. Each was added to rbPrPcoated wells. The binding efficiency of aldolase A was determined by ELISA using HRP-conjugated anti-aldolase A antibody (B). Columns with a different letter asterisks indicate a statistically significant difference $\left(^{*}\right.$ $\left.=p<0.05,{ }^{* *}=p<0.01\right)$. 


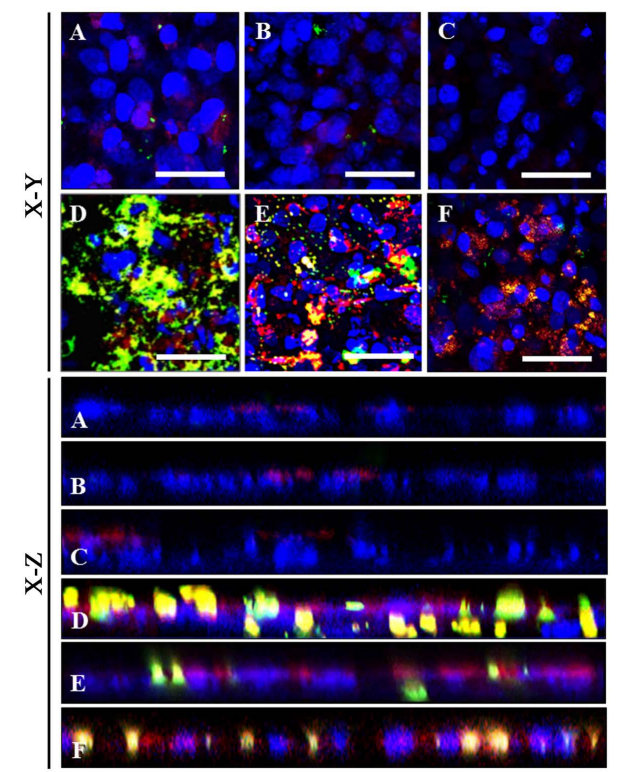

Figure 6. Localization of aldolase A in M-BIE cells. Confocal laser microscopic images show the localizations of aldolase A and incorporated FITC-conjugated particles or $\operatorname{PrP}^{\mathrm{SC}}$ in BIE ((A), (B) and (C)) or M-BIE ((D), (E) and (F)) cells. Briefly, BIE cells were cultured on Transwell inserts for 3 days and treated with or without differentiation medium. After another 3 days culture, non-coated ((A) and (D)) or PrP-coated ((B) and (E)) particles were added to the apical medium. After $9 \mathrm{~h}$, the cells were stained with anti-aldolase A antibody. Aldolase A was visualized with Alexa Fluor 594-conjugated antibody (red). For the other treatments, $\operatorname{PrP}^{\mathrm{Sc}}$ was added to the apical medium of BIE (C) or M-BIE (F) after the induction of M cell differentiation. After $9 \mathrm{~h}$, the cells were immunostained with anti-aldolase A antibody, and their photograph images were taken. The same slides were treated with guanidine hydrochloride and re-stained with anti-PrP antibody clone 132 . $\operatorname{PrP}^{\mathrm{Sc}}$ was visualized with Alexa Fluor 488-conjugated antibody (green). All slides were counterstained with DAPI. The $\mathrm{X}-\mathrm{Z}$ sections are displayed below the lower X-Y sections. Bars $=10 \mu \mathrm{m}$.

number of incorporated particles in M-BIE cells was larger when non-coated particles were used than when PrPcoated particles were used. It is possibly for this reason why M-BIE cells incorporated PrP-coated particles and transported them to the basal medium to a greater extent than BIE cells. $\mathrm{PrP}^{\mathrm{Sc}}$ of $\mathrm{N} 2 \mathrm{aC} 24 \mathrm{~L} 1-3$ cells were added onto BIE and M-BIE cells, and incubated for $9 \mathrm{~h}$. The incorporated $\mathrm{PrP}^{\mathrm{Sc}}$ was co-stained with aldolase A in MBIE cells, but not stained in BIE cells (Figure 6(C) and Figure 6(F)). These results suggest that aldolase A may have the ability to bind to $\mathrm{PrP}^{\mathrm{Sc}}$ in cellular vesicles.

We investigated the effect of aldolase A on the transcytosis of M cells (Figure 7(A)). Briefly, BIE or M-BIE cells were pre-treated with or without goat anti-aldolase A antibody or negative control of goat IgG for 2 hours. Non- or PrP-coated particles were added onto them. After 9 hours, the total number of transported particles in M-BIE cells was significantly greater than that in BIE cells. In addition, M-BIE cells incorporated PrP-coated particles to a greater extent than non-coated particles. However, the pre-treatment of anti-aldolase A antibody clearly inhibited the transportation of PrP-particles by M-BIE, but did not affect the transcytosis of non-coated particles by M-BIE cells. The confocal laser microscopic images clearly show that the pre-treatment of anti-aldolase A severely decreases the incorporation of PrP-particles by M-BIE cells, but not that of non-coated particles (Figure 7(B)). These results suggest that aldolase A may play an important role in the incorporation of prion proteins by intestinal $\mathrm{M}$ cells.

In the villous epithelium, aldolase A was detected on the surface of the epithelium facing the lumen and in the mucus droplet of goblet cells in duodenum, jejunum, ileum and colon (Figures 8(A)-(D)). Lamp-1, a late endosomal maker [26], was sometimes co-localized with aldolase A in the late endosome near by the mucous droplet of goblet cells (Figure 8(E)). Additionally, as MUC2 is known as a mucous marker of goblet cells [36], it was co-stained with aldolase A on the surface of epithelium and in the mucous droplet of goblet cells (Figure 8(F)). These data indicate that aldolase A in the villi is produced and secreted by goblet cells. In the follicle associated epithelium (FAE) of bovine jejunal and ileal Peyer's patches, aldolase A was localized on the surface and apical part of the microfold (M) cells along with CK 18, known as a bovine M cell marker [37] (Figure 9), as same as 

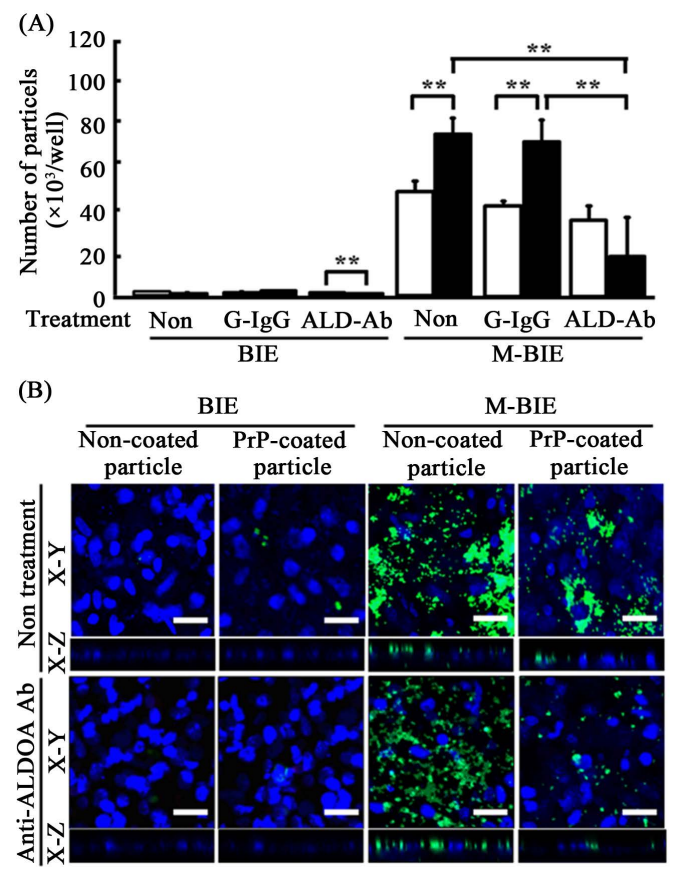

Figure 7. Effect of anti-aldolase A antibody on transcytosis of BIE cells. After M cell-differentiation, BIE and M-BIE cells were pretreated with or without (Non) goat anti-aldolase A (ALD-Ab) or control IgG (G-IgG) antibody for $2 \mathrm{~h}$. Non-coated (open bars) or prion protein-coated (closed bars) particles were added to the apical medium (six wells each). After $9 \mathrm{~h}$ incubation, the basal media were collected. The transported particles were quantified using a FACS calibur flow cytometer (A). In addition, BIE cells were fixed with 4\% PFA and counterstained with DAPI for confocal microscopy (B). Columns with a different letter asterisks indicate a statistically significant difference $\left(^{* *}=p<0.01\right)$. Bars $=10 \mu \mathrm{m}$.

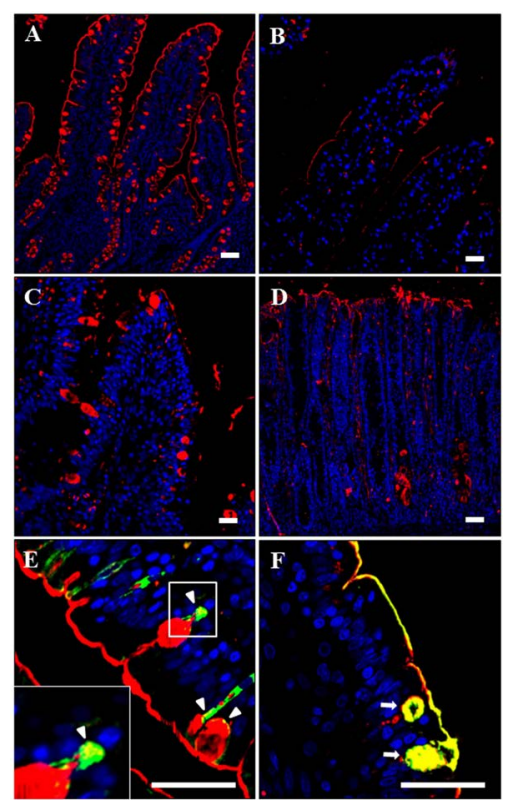

Figure 8. Localization of aldolase A in bovine small intestinal and colonic villous epithelium. Paraffin sections were immunostained with anti-aldolase A antibody in duodenal (A), jejunal (B), ileal (C) and colonic (D) sections. Duodenal goblet cells were dual immunostained with anti-aldolase A and anti-LAMP-1 antibody, as an endosomal marker (E), or MUC2 antibody as a mucous marker (F). Aldolase A was visualized with Alexa Fluor 594-conjugated antibody (red) and LAMP-1 and MUC2 were visualized with Alexa Fluor 488-conjugated antibody (green). The sections were counterstained with DAPI. Bars $=20 \mu \mathrm{m}$. 


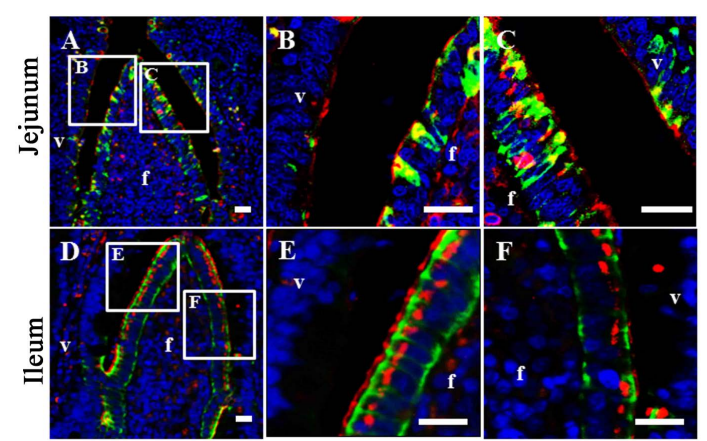

Figure 9. Localization of aldolase A in bovine jejunal and ileal Peyer's patches. Aldolase A was localized in the apical membrane and cytosol of M cells in the FAE. Paraffin sections of jejunal ((A); (B) and (C)) and ileal ((D), (E) and (F)) Peyer's patches were dual immunostained with an anti-aldolase A antibody and anti-CK18 antibody as a bovine intestinal $\mathrm{M}$ cell marker. (B), (C), (E) and (F) are higher magnifications of the boxes in (A) and (D). Aldolase A was visualized with Alexa Fluor 594-conjugated antibody (red) and CK18 was visualized with Alexa Fluor 488-conjugated antibody (green). Arrowheads indicated the small granule vesicles near the mucous droplet of goblet cells. Arrows indicated the mucous droplet of goblet cells. The sections were counterstained with DAPI. Bars $=20 \mu \mathrm{m}$. v: villous epithelium, f: follicle.

the localization of aldolase A in the M-BIE cells in vitro (Figure 6). As CK-18-negative cells did not express aldolase A, this suggests that aldolase A may be a marker of M cells in the FAE (Figure 9(B), Figure 9(C) and Figure 9(F)).

In $\mathrm{M}$ cells, aldolase A was visualized with gold particles in microfold and small granule vesicles by immunoelectron microscopic analysis (Figures 10(A)-(C)). In addition, there were a lot of large vesicles containing aldolase A in M cells, including transport vesicles for transcytosis (Figure 10(C)). In absorptive epitheliocytes, aldolase A was often detected in microvilli clearly, but in small granule vesicles it was hardly detected (Figures 10(D)-(F)). Furthermore, aldolase A was stained in the microvilli, mucus droplet and small granule vesicles of goblet cells (Figures 10(G)-(I)). These results were similar to the immunostaining (Figure 9(E) and Figure 9(F)). These results revealed that bovine $M$ cells and goblet cells synthesized aldolase A and secreted it to the microvilli of the intestinal tract.

\section{Discussion}

For oral transmission, $\mathrm{PrP}^{\mathrm{Sc}}$ first must cross the intestinal epithelium to successfully infect the body. We previously reported that orally delivered $\mathrm{PrP}^{\mathrm{Sc}}$ was incorporated by M cells in FAE of Peyer's patches [25], and that $\mathrm{M}$ cell-differentiated BIE cells (M-BIE cells) were able to transcytosePrP ${ }^{\mathrm{Sc}}$ in our in vitro model [29]. However, the exact mechanisms for intestinal invasion of $\mathrm{PrP}^{\mathrm{Sc}}$ still are unknown. In this research, aldolase A was identified as a PrP-binding protein in the vesicles of M-BIE cells following proteomic analysis. Aldolase A, a glycolytic pathway enzyme, cleaves fructose-1,6-bisphosphate to dihydroxyacetone phosphate and glyceraldehyde-3phosphate, which are then degraded to pyruvate by the classical enzymes of the Embden-Meyerhof pathway [38]. Aldolase exists primarily as three isozymes: aldolase A, B and C, which are predominantly expressed in muscle, liver and brain, respectively [39] [40]. Aldolase is known to be secreted into the blood from each of these organs, following metabolic disorders and cellular damage from hepatitis and inflammatory bowel disease, etc. [41]-[43]. We reveal in this report that aldolase A was secreted from $\mathrm{M}$ cells in the bovine intestine.

Aldolase A in the FAE of the Peyer's patch was specifically stained in both the microfold and apical part of $\mathrm{M}$ cells, but not stained in CK-18-negative cells. The amount of aldolase A was greater in $\mathrm{M}$ cells following differentiation than in the undifferentiated BIE cells. We previously reported that a specific marker for bovine M cells was an intermediate filament protein CK18 [37]. The lack of alkaline phosphatase activity on $\mathrm{M}$ cells has also been used to identify this cell type in some species [44]. Glycoprotein 2 was not only highly expressed on the surface of $\mathrm{M}$ cells but was also concerned with the selective invasion of $\mathrm{FimH}^{+}$bacteria by $\mathrm{M}$ cells [45] Although there are few studies with regard to enzymes expressed in intestinal $\mathrm{M}$ cells, sphingosine-1-phosphate lyase is expressed in FAE of C57BL/6 mice [46]. However, Caco-2 cells, a human intestinal epithelium cell line, has the ability to differentiate into M cells and express aldolase A [47] [48]. Accordingly, aldolase A may be a potential new specific marker of bovine intestinal $M$ cells in the FAE. 


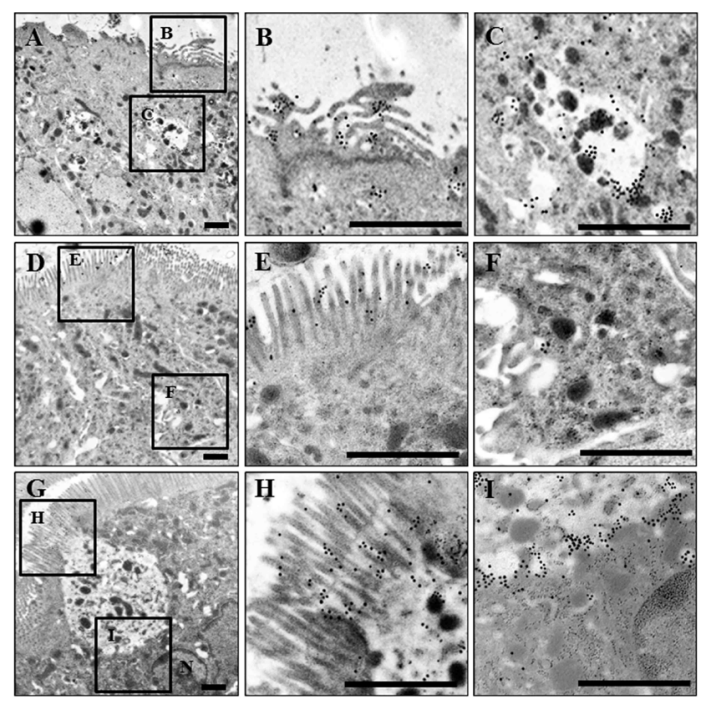

Figure 10. Immunoelectron microscopic ultrastructural localization of aldolase A in bovine intestinal epithelium. Immunoelectron microscopic sections were immunostained with anti-aldolase A antibody in $\mathrm{M}$ cell ((A), (B), (C)), absorptive epithelium cells ((D), (E), (F)) and goblet cells ((G), (H), (I)) of bovine ileum. Aldolase A was visualized with $15 \mathrm{~nm}$ gold particle-conjugated second antibody. B, C, E, F, H and I are higher magnifications of the boxes in (A), (D) and (G). Bars $=1 \mu \mathrm{m}$.

We show that a large amount of aldolase A is detected in the micro villi of the small intestine, and this was shown to be secreted from goblet cells. A recent study reported that goblet cells delivered luminal antigen to CD103+ DCs in the small intestine, and that the preferential delivery of antigens to DCs with tolerogenic properties implies a key role for this goblet cells function in intestinal immune homeostasis [49]. In addition, Mycobacterium avium complex binds to intestinal mucus aldolase B, conceivably facilitating intestinal colonization of the organism [50]. Intestinal aldolase A may affect the intestinal barrier and have a potential important role in gut immunity.

We have demonstrated using far-western blot analysis, ELISA and immunoprecipitation, that aldolase A has the ability to bind to PrP. Many studies have identified PrP-interacting and -binding partners, such as $\mathrm{Cu}^{2+}, \mathrm{Ni}^{2+}$, glycosaminoglycans, DNA, RNA, a number of signaling proteins, histone H3, and thiamine etc. [51]-[54]. In addition to classical function in glycolysis, aldolase has been implicated in insulin-dependent glucose transport mediated by GLUT4, and appears to be a major calmodulin-dependent protein kinase phosphatase-binding protein in the brain [55] [56]. These studies indicated that $\operatorname{PrP}$ and aldolase have a potential ability of binding to many substances. In a previous study, far-western blot analysis confirmed that aldolase $\mathrm{C}$ is able to bind to $\mathrm{PrP}^{\mathrm{Sc}}$ [57]. Recent reports show that Purkinje cells with neurotoxic prion-like protein Doppel specifically express aldolase [58]. Moreover, Aldolase A is highly expressed in the cerebrospinal fluid of sporadic CJD patients and the cerebellum of scrapie-infected mice [59] [60]. In this study, $\mathrm{PrP}-$ particles and $\operatorname{PrP}^{\mathrm{Sc}}$ were co-stained with aldolase A in the vesicles of M-BIE cells. Furthermore, immunoelectron microscopy revealed that aldolase A was localized in transport vesicles in bovine intestinal $\mathrm{M}$ cells. Unlike enterocytes, $\mathrm{M}$ cells are adept at transcytosing materials from their apical surface to the basolateral membrane. These data suggest that transcytosis may be a receptor-mediated process performed by the $\mathrm{M}$ cells using aldolase $\mathrm{A}$.

In conclusion, we have identified aldolase $\mathrm{A}$ as a PrP-binding protein in the vesicles of $\mathrm{M}$ cells. Far-Western blot, immunoprecipitation and ELISA analysis revealed the specific binding ability of aldolase A to PrP. Aldolase A was localized at the epithelia of the mucus droplet of goblet cells and M cells of FAE of in bovine Peyer's patches. Aldolase A may therefore be an intestinal M cell marker in the FAE. Further, aldolase A was abundantly synthesized and secreted in M cells. These results suggest that aldolase A-positive M cells in Peyer's patches may actively transcytose $\mathrm{Pr}^{\mathrm{Sc}}$ into the basolateral side of the epithelium and can play a key role in promoting intestinal immune homeostasis by delivering a luminal antigen. This study contributes to the understanding of the function of M cells and the invasion mechanisms of BSE agents by bovine intestinal epithelial cells. After the text edit has been completed, the paper is ready for the template. Duplicate the template file by using the Save As command, and use the naming convention prescribed by your journal for the name of your 
paper. In this newly created file, highlight all of the contents and import your prepared text file. You are now ready to style your paper.

\section{Acknowledgements}

This research was supported by a Grant-in-Aid for Scientific Research (24380150) from the Ministry of Education, Culture, Sports, Science and Technology, BSE Control Project from the Ministry of Agriculture, Forestry and Fisheries and Cooperative Research Grant of the Institute for Enzyme Research and Cooperative Research Grant of the Institute for Enzyme Research, the University of Tokushima. Yuya Nagasawa was also supported by a Grant-in-Aid for Scientific Research (25-2872) from the Ministry of Education, Culture, Sports, Science and Technology, Japan Society for the Promotion of Science (JSPS), Research Fellowship for Young Scientists Program.

\section{References}

[1] Kindon, H., Pothoulakis, C., Thim, L., Lynch-Devaney, K. and Podolsky, D.K. (1995) Trefoil Peptide Protection of Intestinal Epithelial Barrier Function: Cooperative Interaction with Mucin Glycoprotein. Gastroenterology, 109, 516523. http://www.ncbi.nlm.nih.gov/pubmed/7615201 http://dx.doi.org/10.1016/0016-5085(95)90340-2

[2] Bals, R. (2000) Epithelial Antimicrobial Peptides in Host Defense against Infection. Respiratory Research, 1, $141-150$. http://dx.doi.org/10.1186/rr25

[3] Hase, K. and Ohno, H. (2006) Epithelial Cells as Sentinels in Mucosal Immune Barrier. Nihon Rinsho Meneki Gakkai Kaishi, 29, 16-26. http://www.ncbi.nlm.nih.gov/pubmed/16505599 http://dx.doi.org/10.2177/jsci.29.16

[4] Wershil, B.K. and Furuta, G.T. (2008)4. Gastrointestinal Mucosal Immunity. Journal of Allergy and Clinical Immunology, 121, S380-S383. http://dx.doi.org/10.1016/j.jaci.2007.10.023

[5] Nagi, A.M. and Babiuk, L.A. (1988) Preparation, Purification and Characterization of Bovine Peyer’s Patch Leukocytes. Canadian Journal of Veterinary Research, 52, 249-257.

[6] Nagi, A.M. and Babiuk, L.A. (1989) Characterization of Surface Markers of Bovine Gut Mucosal Leukocytes Using Monoclonal Antibodies. Veterinary Immunology and Immunopathology, 22, 1-14.

http://www.ncbi.nlm.nih.gov/pubmed/2603381 http://dx.doi.org/10.1016/0165-2427(89)90159-1

[7] Liebler, E.M., Pohlenz, J.F. and Cheville, N.F. (1988) Gut-Associated Lymphoid Tissue in the Large Intestine of Calves. II. Electron Microscopy. Veterinary Pathology, 25, 509-515. http://dx.doi.org/10.1177/030098588802500615

[8] Jung, C., Hugot, J.-P. and Barreau, F. (2010) Peyer's Patches: The Immune Sensors of the Intestine. International Journal of Inflammation, 2010, Article ID: 823710. http://dx.doi.org/10.4061/2010/823710

[9] Reynolds, J.D. and Morris, B. (1983) The Evolution and Involution of Peyer's Patches in Fetal and Postnatal Sheep. European Journal of Immunology, 13, 627-635. http://dx.doi.org/10.1002/eji.1830130805

[10] Landsverk, T., Halleraker, M., Aleksandersen, M., McClure, S., Hein, W. and Nicander, L. (1991) The Intestinal Habitat for Organized Lymphoid Tissues in Ruminants; Comparative Aspects of Structure, Function and Development. Veterinary Immunology and Immunopathology, 28, 1-16. http://www.ncbi.nlm.nih.gov/pubmed/1905075 http://dx.doi.org/10.1016/0165-2427(91)90038-E

[11] Pabst, R., Geist, M., Rothkotter, H.J., Centre, F.J.F., Rothkötter, H.J. and Fritz, F.J. (1988) Postnatal Development and Lymphocyte Production of Jejunal and Ileal Peyer's Patches in Normal and Gnotobiotic Pigs. Immunology, 64, 539544. http://www.pubmedcentral.nih.gov/articlerender.fcgi?artid=1385070\&tool=pmcentrez\&rendertype=abstract

[12] HogenEsch, H. and Felsburg, P.J. (1992) Isolation and Phenotypic and Functional Characterization of Cells from Peyer's Patches in the Dog. Veterinary Immunology and Immunopathology, 31, 1-10. http://www.ncbi.nlm.nih.gov/pubmed/1570673

[13] Gebert, A. (1997) The Role of M Cells in the Protection of Mucosal Membranes. Histochemistry and Cell Biology, 108, 455-470. http://www.ncbi.nlm.nih.gov/pubmed/9450628 http://dx.doi.org/10.1007/s004180050186

[14] Miyazawa, K., Aso, H., Kanaya, T., Kido, T., Minashima, T., Watanabe, K., et al. (2006) Apoptotic Process of Porcine Intestinal M Cells. Cell and Tissue Research, 323, 425-432. http://dx.doi.org/10.1007/s00441-005-0086-z

[15] Landsverk, T. (1988) Phagocytosis and Transcytosis by the Follicle-Associated Epithelium of the Ileal Peyer's Patch in Calves. Immunology and Cell Biology, 66, 261-268. http://dx.doi.org/10.1038/icb.1988.35 
[16] Beyaz, F. and Aşti, R.N. (2004) Development of Ileal Peyer's Patches and Follicle Associated Epithelium in Bovine Foetuses. Anatomia, Histologia, Embryologia, 33, 172-179. http://dx.doi.org/10.1111/j.1439-0264.2004.00530.x

[17] Kraehenbuhl, J.P. and Neutra, M.R. (2000) Epithelial M Cells: Differentiation and Function. Annual Review of Cell and Developmental Biology, 16, 301-332. http://dx.doi.org/10.1146/annurev.cellbio.16.1.301

[18] Nochi, T., Yuki, Y., Matsumura, A., Mejima, M., Terahara, K., Kim, D.Y., et al. (2007) A Novel M Cell-Specific Carbohydrate-Targeted Mucosal Vaccine Effectively Induces Antigen-Specific Immune Responses. Journal of Experimental Medicine, 204, 2789-2796. http://dx.doi.org/10.1084/jem.20070607

[19] Will, R.G., Ironside, J.W., Zeidler, M., Cousens, S.N., Estibeiro, K., Alperovitch, A., et al. (1996) A New Variant of Creutzfeldt-Jakob Disease in the UK. Lancet, 347, 921-925. http://dx.doi.org/10.1016/S0140-6736(96)91412-9

[20] Novakofski, J., Brewer, M.S., Mateus-Pinilla, N., Killefer, J. and McCusker, R.H. (2005) Prion Biology Relevant to Bovine Spongiform Encephalopathy. Journal of Animal Science, 83, 1455-1476. http://www.journalofanimalscience.org/content/83/6/1455

[21] Hill, A.F., Desbruslais, M., Joiner, S., Sidle, K.C., Gowland, I., Collinge, J., et al. (1997) The Same Prion Strain Causes vCJD and BSE. Nature, 389, 448-450. http://dx.doi.org/10.1038/38925

[22] Bolton, D.C., McKinley, M.P., Prusiner, S.B., Bolton, D.C. and McKinley, M.P. (1982) Identification of a Protein That Purifiles with the Scrapie Prion. Science, 218, 1309-1311. http://www.ncbi.nlm.nih.gov/pubmed/6815801

[23] Wadsworth, J.D., Joiner, S., Hill, A.F., Campbell, T.A., Desbruslais, M., Luthert, P.J. and Collinge, J. (2001) Tissue Distribution of Protease Resistant Prion Protein in Variant Creutzfeldt-Jakob Disease Using a Highly Sensitive Immunoblotting Assay. Lancet, 358, 171-180. http://www.ncbi.nlm.nih.gov/pubmed/11476832 http://dx.doi.org/10.1016/S0140-6736(01)05403-4

[24] Espinosa, C., Herva, M.E., Andréoletti, O., Padilla, D., Lacroux, C., Cassard, H., et al. (2009) Transgenic Mice Expressing Porcine Prion Protein Resistant to Classical Scrapie but Susceptible to Sheep Bovine Spongiform Encephalopathy and Atypical Scrapie. Emerging Infectious Diseases, 15, 1214-1221. http://dx.doi.org/10.3201/eid1508.081218

[25] Takakura, I., Miyazawa, K., Kanaya, T., Itani, W., Watanabe, K., Ohwada, S., et al. (2011) Orally Administered Prion Protein Is Incorporated by M Cells and Spreads into Lymphoid Tissues with Macrophages in Prion Protein Knockout Mice. American Journal of Pathology, 179, 1301-1309. http://dx.doi.org/10.1016/j.ajpath.2011.05.058

[26] Kujala, P., Raymond, C.R., Romeijn, M., Godsave, S.F., van Kasteren, S.I., Wille, H., et al. (2011) Prion Uptake in the Gut: Identification of the First Uptake and Replication Sites. PLoS Pathogens, 7, e1002449. http://dx.doi.org/10.1371/journal.ppat.1002449

[27] Donaldson, D.S., Kobayashi, A., Ohno, H., Yagita, H., Williams, I.R. and Mabbott, N.A. (2012) M Cell-Depletion Blocks Oral Prion Disease Pathogenesis. Mucosal Immunology, 5, 216-225. http://dx.doi.org/10.1038/mi.2011.68

[28] Miyazawa, K., Hondo, T., Kanaya, T., Tanaka, S., Takakura, I., Itani, W., et al. (2010) Characterization of Newly Established Bovine Intestinal Epithelial Cell Line. Histochemistry and Cell Biology, 133, 125-134. http://dx.doi.org/10.1007/s00418-009-0648-3

[29] Miyazawa, K., Kanaya, T., Takakura, I., Tanaka, S., Hondo, T., Watanabe, H., et al. (2010) Transcytosis of MurineAdapted Bovine Spongiform Encephalopathy Agents in an in Vitro Bovine M Cell Model. Journal of Virology, 84, 12285-12291. http://dx.doi.org/10.1128/JVI.00969-10

[30] Yamasaki, T., Suzuki, A., Shimizu, T., Watarai, M., Hasebe, R. and Horiuchi, M. (2012) Characterization of Intracellular Localization of $\mathrm{PrP}^{\mathrm{Sc}}$ in Prion-Infected Cells Using a mAb that Recognizes the Region Consisting of aa 119-127 of Mouse PrP. Journal of General Virology, 93, 668-680. http://jgv.sgmjournals.org/content/93/3/668.short

[31] Hondo, T., Kanaya, T., Takahashi, Y., Watanabe, H., Ohwada, S., Watanabe, K., et al. (2010) Optimum Condition of in Vitro M Cell Differentiation in Bovine Intestinal Epithelial Cell Line (BIE). Tohoku Animal Science and Technology Society, 59, 49-53.

[32] Fujita, K., Yamaguchi, Y., Mori, T., Muramatsu, N., Miyamoto, T., Yano, M., et al. (2011) Effects of a Brain-Engraftable Microglial Cell Line Expressing Anti-Prion scFv Antibodies on Survival Times of Mice Infected with Scrapie Prions. Cellular and Molecular Neurobiology, 31, 999-1008. http://dx.doi.org/10.1007/s10571-011-9696-z

[33] Uchiyama, K., Muramatsu, N., Yano, M., Usui, T., Miyata, H. and Sakaguchi, S. (2013) Prions Disturb Post-Golgi Trafficking of Membrane Proteins. Nature Communications, 4, Article Number: 1846. http://dx.doi.org/10.1038/ncomms2873

[34] Pappin, D.J., Hojrup, P. and Bleasby, A.J. (1993) Rapid Identification of Proteins by Peptide-Mass Fingerprinting. Current Biology, 3, 327-332. http://dx.doi.org/10.1016/0960-9822(93)90195-T

[35] Claude, P. and Goodenough, D.A. (1973) Fracture Faces of Zonulae Occludentes from “Tight” and “Leaky” Epithelia. Journal of Cell Biology, 58, 390-400. http://dx.doi.org/10.1083/jcb.58.2.390

[36] Rodríguez-Piñeiro, A.M., Bergström, J.H., Ermund, A., Gustafsson, J.K., Schütte, A., Johansson, M.E.V. and Hansson, 
G.C. (2013) Studies of Mucus in Mouse Stomach, Small Intestine, and Colon. II. Gastrointestinal Mucus Proteome Reveals Muc2 and Muc5ac Accompanied by a Set of Core Proteins. American Journal of Physiology-Gastrointestinal and Liver Physiology, 305, G348-G356. http://dx.doi.org/10.1152/ajpgi.00047.2013

[37] Hondo, T., Kanaya, T., Takakura, I., Watanabe, H., Takahashi, Y., Nagasawa, Y., et al. (2011) Cytokeratin 18 Is a Specific Marker of Bovine Intestinal M Cell. American Journal of Physiology-Gastrointestinal and Liver Physiology, 300, G442-G453. http://dx.doi.org/10.1152/ajpgi.00345.2010

[38] Zgiby, S.M., Thomson, G.J., Qamar, S. and Berry, A. (2000) Exploring Substrate Binding and Discrimination in Fructose1, 6-bisphosphate and Tagatose 1,6-Bisphosphate Aldolases. European Journal of Biochemistry, 267, 1858-1868. http://www.ncbi.nlm.nih.gov/pubmed/10712619 http://dx.doi.org/10.1046/j.1432-1327.2000.01191.x

[39] Penhoet, E., Rajkumar, T. and Rutter, W.J. (1966) Multiple Forms of Fructose Diphosphate Aldolase in Mammalian Tissues. Proceedings of the National Academy of Sciences of the United States of America, 56, 1275-1282. http://dx.doi.org/10.1073/pnas.56.4.1275

[40] Penhoet, E.E., Kochman, M. and Rutter, W.J. (1969) Molecular and Catalytic Properties of Aldolase C. Biochemistry, 8, 4396-4402. http://www.ncbi.nlm.nih.gov/pubmed/4982047 http://dx.doi.org/10.1021/bi00839a026

[41] Royds, J.A., Kennedy, H.J., Little, P.V., Taylor, C.B. and Triger, D.R. (1987) Serum Aldolase Isoenzymes in Benign and Malignant Liver Disease. Clinica Chimica Acta, 167, 237-246. http://www.ncbi.nlm.nih.gov/pubmed/3621611 http://dx.doi.org/10.1016/0009-8981(87)90343-3

[42] Maniratanachote, R., Shibata, A., Kaneko, S., Yamamori, I., Wakasugi, T., Sawazaki, T., et al. (2005) Detection of Autoantibody to Aldolase B in Sera from Patients with Troglitazone-Induced Liver Dysfunction. Toxicology, 216, 1523. http://dx.doi.org/10.1016/j.tox.2005.07.012

[43] Vermeulen, N., Vermeire, S., Arijs, I., Michiels, G., Ballet, V., Derua, R., et al. (2011) Seroreactivity against Glycolytic Enzymes in Inflammatory Bowel Disease. Inflammatory Bowel Diseases, 17, 557-564. http://dx.doi.org/10.1002/ibd.21388

[44] Jepson, M.A., Simmons, N.L., Hirst, G.L. and Hirst, B.H. (1993) Identification of M Cells and Their Distribution in Rabbit Intestinal Peyer's Patches and Appendix. Cell and Tissue Research, 273, 127-136. http://dx.doi.org/10.1007/BF00304619

[45] Hase, K., Kawano, K., Nochi, T., Pontes, G.S., Fukuda, S., Ebisawa, M., et al. (2009) Uptake through Glycoprotein 2 of $\mathrm{FimH}^{+}$Bacteria by M Cells Initiates Mucosal Immune Response. Nature, 462, 226-230. http://dx.doi.org/10.1038/nature08529

[46] Borowsky, A.D., Bandhuvula, P., Kumar, A., Yoshinaga, Y., Nefedov, M., Fong, L.G., et al. (2012) Sphingosine-1Phosphate Lyase Expression in Embryonic and Adult Murine Tissues. Journal of Lipid Research, 53, 1920-1931. http://dx.doi.org/10.1194/jlr.M028084

[47] Kerneis, S., Bogdanova, A., Kraehenbuhl, J.P. and Pringault, E. (1997) Conversion by Peyer’s Patch Lymphocytes of Human Enterocytes into M Cells that Transport Bacteria. Science, 277, 949-952.

[48] Roxström-Lindquist, K., Ringqvist, E., Palm, D. and Svärd, S. (2005) Giardia lamblia-Induced Changes in Gene Expression in Differentiated Caco-2 Human Intestinal Epithelial Cells. Infection and Immunity, 73, 8204-8208. http://dx.doi.org/10.1128/IAI.73.12.8204-8208.2005

[49] McDole, J.R., Wheeler, L.W., McDonald, K.G., Wang, B., Konjufca, V., Knoop, K.A., et al. (2012) Goblet Cells Deliver Luminal Antigen to CD103 ${ }^{+}$Dendritic Cells in the Small Intestine. Nature, 483, 345-349. http://dx.doi.org/10.1038/nature10863

[50] Reddy, V.M., Suleman, F.G. and Hayworth, D.A. (2004) Mycobacterium avium Binds to Mouse Intestinal Mucus Aldolase. Tuberculosis, 84, 303-310. http://dx.doi.org/10.1016/j.tube.2003.11.002

[51] Cai, H., Xie, Y., Hu, L., Fan, J. and Li, R. (2013) Prion Protein $\left(\operatorname{PrP}^{\mathrm{c}}\right)$ Interacts with Histone H3 Confirmed by Affinity Chromatography. Journal of Chromatography B, 929, 40-44. http://dx.doi.org/10.1016/j.jchromb.2013.04.003

[52] Zafar, S., von Ahsen, N., Oellerich, M., Zerr, I., Schulz-Schaeffer, W.J., Armstrong, V.W., et al. (2011) Proteomics Approach to Identify the Interacting Partners of Cellular Prion Protein and Characterization of Rab7a Interaction in Neuronal Cells. Journal of Proteome Research, 10, 3123-3135. http://dx.doi.org/10.1021/pr2001989

[53] Perez-Pineiro, R., Bjorndahl, T.C., Berjanskii, M.V., Hau, D., Li, L., Huang, A., et al. (2011) The Prion Protein Binds Thiamine. FEBS Journal, 278, 4002-4014. http://dx.doi.org/10.1111/j.1742-4658.2011.08304.x

[54] Caughey, B. and Baron, G.S. (2006) Prions and Their Partners in Crime. Nature, 443, 803-810. http://dx.doi.org/10.1038/nature05294

[55] Kao, A.W., Noda, Y., Johnson, J.H., Pessin, J.E. and Saltiel, A.R. (1999) Aldolase Mediates the Association of F-Actin with the Insulin-Responsive Glucose Transporter GLUT4. Journal of Biological Chemistry, 274, 17742-17747. 
http://dx.doi.org/10.1074/jbc.274.25.17742

[56] Ishida, A., Tada, Y., Nimura, T., Sueyoshi, N., Katoh, T., Takeuchi, M., et al. (2005) Identification of $\mathrm{Major} \mathrm{Ca}^{2+} /$ Calmodulin-Dependent Protein Kinase Phosphatase-Binding Proteins in Brain: Biochemical Analysis of the Interaction. Archives of Biochemistry and Biophysics, 435, 134-146. http://dx.doi.org/10.1016/j.abb.2004.11.022

[57] Strom, A., Diecke, S., Hunsmann, G. and Stuke, A.W. (2006) Identification of Prion Protein Binding Proteins by Combined Use of Far-Western Immunoblotting, Two Dimensional Gel Electrophoresis and Mass Spectrometry. Proteomics, 6, 26-34. http://dx.doi.org/10.1002/pmic.200500066

[58] Royds, J.A., Ironside, J.W., Warnaar, S.O., Taylor, C.B. and Timperley, W.R. (1987) Monoclonal Antibody to Aldolase C: A Selective Marker for Purkinje Cells in the Human Cerebellum. Neuropathology and Applied Neurobiology, 13, 11-21. http://www.ncbi.nlm.nih.gov/pubmed/3553977

[59] Gawinecka, J., Dieks, J., Asif, A.R., Carimalo, J., Heinemann, U., Streich, J.H., et al. (2010) Codon 129 Polymorphism Specific Cerebrospinal Fluid Proteome Pattern in Sporadic Creutzfeldt-Jakob Disease and the Implication of Glycolytic Enzymes in Prion-Induced Pathology. Journal of Proteome Research, 9, 5646-5657. http://dx.doi.org/10.1021/pr1004604

[60] Jang, B., Kim, E., Choi, J.K., Jin, J.K., Kim, J.I., Ishigami, A., et al. (2008) Accumulation of Citrullinated Proteins by Up-Regulated Peptidylarginine Deiminase 2 in Brains of Scrapie-Infected Mice: A Possible Role in Pathogenesis. American Journal of Pathology, 173, 1129-1142. http://dx.doi.org/10.2353/ajpath.2008.080388 